\title{
Trace elements in scalp hair from potentially exposed individuals in the vicinity of the Bayan Obo mine in Baotou, China
}

\author{
Yuxue Pan, Haitao $\mathrm{Li}^{*}$ \\ Key Laboratory of Land Surface Pattern and Simulation, Institute of Geographical Sciences and Natural Resources Research, Chinese Academy of Sciences, \\ Beijing 100101, China
}

\section{A R T I C L E I N F O}

\section{Article history:}

Received 21 March 2015

Received in revised form 25 August 2015

Accepted 30 August 2015

Available online 2 September 2015

\section{Keywords:}

Chemical elements

Biomonitoring

Hair analysis

Mining sites

Environmental exposure

\begin{abstract}
A B S T R A C T
Mining activities including mineral excavation and ore transportation produce and release large amounts of pollutants to the surrounding environment, raising concerns regarding the effects of environmental exposure to pollutants on human health. The concentration of elements in hair can be used as a biomarker of exposure to chemical elements. In the present study, hair samples from 89 relatively healthy volunteers aged 11-77 years old (57 living near Bayan Obo giant REE-Nb-Fe ore deposit and 32 in non-mining areas) from Baotou (Inner Mongolia, China) were analyzed to determine the contents of 25 chemical elements (Ag, Al, As, Ba, Bi, Ca, Cd, Co, Cr, Cs, Cu, Fe, Ga, Li, Mg, Mn, Mo, Ni, Pb, Rb, Se, Tl, U, V and Zn) with the aim of gaining insights about the potential exposure to chemical elements of the population living within the Bayan Obo opencast mining area. The effects of gender and living area on element concentrations in hair were also investigated. The results showed that the mean concentrations of the target elements (Ag, Al, Ba, Cd, Co, Li, Mn, Ni, Pb, Tl, V, Cs, Ga, Rb, U, Bi, Mo, As, Ca, Fe, Mg and Zn) in human hair from the mining area (MA) were primarily higher than that in non-mining areas (NMA). The area of residence had an influence on the presence of select trace elements ( $\mathrm{As}, \mathrm{Cd}, \mathrm{Mg}, \mathrm{Pb}, \mathrm{Tl}, \mathrm{U}$ and $\mathrm{Zn}$ ) in human hair. In addition, the hair samples from MA showed statistically significant differences between males and females for a larger number of elements than those in NMA in which only Ag, Bi and Se were significantly different. This result implies a potential influence of mining activities on residents living in the vicinity. These findings confirm the need for competent authorities to act as early as possible and to implement strategies aimed to protect exposed populations and the entire ecosystem.
\end{abstract}

(c) 2015 Elsevier B.V. All rights reserved.

\section{Introduction}

Concern regarding the effects of environmental exposure to trace elements on human health has driven the scientific community to identify reliable tools and methods for assessing the effect of the emissions of trace elements from anthropogenic activities. Therefore, biological monitoring has been extensively employed, and blood, urine, feces, hair and nails are the biological materials most frequently analyzed to ascertain the levels of trace elements (Elinder et al., 1988; Kučera et al., 1995).

Among the biological materials, hair is an attractive choice for occupational and environmental health surveys and has the following advantages over other biological samples. Firstly, hair is mainly composed of keratin, a protein rich in cysteine sulfhydryl (thiol) groups that can bind various elements (Burger et al., 1994).

\footnotetext{
* Corresponding author.

E-mail address: liht@igsnrr.ac.cn (H. Li).
}

Therefore, elements circulating in the blood can accumulate in the hair as hair shaft continuously contact the bloodstream at the hair follicle during growth (McLean et al., 2009). As a consequence, hair may reflect tissue metal concentrations. Additionally, melanin pigments can bind cations by ionic interaction at physiological pHs because melanin are polyanionic polymers containing negatively charged carboxyl groups and semiquinones (Larsson, 1993). Moreover, uncharged metals, such as elemental $\mathrm{Hg}$, may also bind to the hydrophobic core of the melanin polymer in the hair structure (Kronstrand et al., 1999). All of these chemical interactions allow trace elements to be persistent in human hair for a significant amount of time. Therefore, hair can serve as a useful sample for noninvasive environmental health surveys (Gil et al., 2011). Secondly, hair is highly stable with a high capacity to accumulate metals during extended periods and its collection and transportation is simple. It has been reported that the metal concentrations found in hair are usually ten times higher than those in blood and urine (MoredaPineiro et al., 2007; Pereira et al., 2004). Thirdly, human hair grows at a rate of approximately $1 \mathrm{~cm}$ per month, allows for long-term 
monitoring of past and recent exposure and does not show changes in storage; thus, the level of an element in hair reflects the level in the body from which the hair was formed and provides a historical record of the assimilation of elements from the environment (Foo et al., 1993; Gil et al., 2011). These advantages resulted in the widespread use of trace element analyses in hair as a tool for biological investigation of nutrition, growth and development, and disease processes. Furthermore, trace element analyses are conducive not only to present evaluations and estimations, but also to the reconstruction of past biological events (Afridi et al., 2011; Li et al., 2011; Luo et al., 2014; Peña-Fernández et al., 2014; Sahoo et al., 2014; Varrica et al., 2014a).

Mining is one of the oldest activities in human civilization and is a vital economic sector for many countries (Coelho et al., 2011). Mining is also one of the most hazardous activities for environmental and public health because mining may release various trace elements into the surrounding environment. This release contaminates the air, ground and surface waters, soils and plants, causing health risks among local residents (Bech et al., 1997; Chehregani et al., 2009; Coelho et al., 2014; Monna et al., 2004; Ullrich et al., 1999).

The Bayan Obo giant REE-Nb-Fe ore deposit of Baotou, Inner Mongolia, China $\left(110^{\circ} \mathrm{E}, 41^{\circ} 48^{\prime} \mathrm{N}\right)$ is the largest rare earth element (REE) mineral deposit in the world and a major producer of Fe and Nb (Drew et al., 1990). After years of opencast mining and ore processing, large amounts of pollutants resulting from the long-lasting mining activities are present throughout the district and are responsible for unusually high concentrations of trace elements (Guo et al., 2013). Moreover, Baotou REE tailings, produced by Baotou Iron and Steel Company, were China's largest rare earths producer. Because the tailing is powdery and composed of various mineral matters, abundant tailing powders with high concentrations of trace elements can enter the atmosphere and the soil easily due to strong winds occurring all year in this region. The presence and accumulation of trace elements in atmospheric particulates and soil would threaten the surrounding ecosystem (Wang et al., 2014). Thus, the Bayan Obo giant REE-Nb-Fe ore deposit has been one of the major pollution sources for the surrounding environment (Wang and Liang, 2014).

However, few studies have investigated the trace element exposure of the population living within the mining area of Inner Mongolia of China. With the background mentioned above, the goal of our study was to characterize the levels of 25 trace elements (Ag, $\mathrm{Al}, \mathrm{As}, \mathrm{Ba}, \mathrm{Bi}, \mathrm{Ca}, \mathrm{Cd}, \mathrm{Co}, \mathrm{Cr}, \mathrm{Cs}, \mathrm{Cu}, \mathrm{Fe}, \mathrm{Ga}, \mathrm{Li}, \mathrm{Mg}, \mathrm{Mn}, \mathrm{Mo}, \mathrm{Ni}, \mathrm{Pb}, \mathrm{Rb}$, $\mathrm{Se}, \mathrm{Tl}, \mathrm{U}, \mathrm{V}$ and $\mathrm{Zn}$ ) in the hair of residents. Additionally, a comparative investigation of elemental contents in human hair from the mining area (MA) and non-mining areas (NMA) was conducted in this paper.

\section{Materials and methods}

\subsection{Study area}

Baotou $\left(40^{\circ} 23^{\prime}-41^{\circ} 07^{\prime} \mathrm{N}, 109^{\circ} 14^{\prime}-110^{\circ} 52^{\prime} \mathrm{E}\right)$, located in the Midwest of Inner Mongolia, China, is an integrated industrial city based on metallurgy, rare earth production and machinery manufacturing. The Bayan Obo giant REE-Nb-Fe ore deposit, lying in the northern of Baotou city, is the most important REE and Nb metalorganic province in the world since the discovery of the main orebody in 1927 (Drew et al., 1990). The Bayan Obo mine is, to date, the largest light rare earth deposit with reserves reported to be over 1.5 billion tonnes of iron ore (average grade 35\%), 48 million tonnes of REE (average grade 6\%) and approximately 1 million tonnes of niobium (average grade 0.13\%) (Smith et al., 1999). Every year, the Banyan Obo mine produces approximately 8 million tonnes of tailings, which usually is simply disposed in open dumps.

\subsection{Sampling}

A total of 89 residents (43 females and 46 males, 11-77 years old) living in Baotou, Inner Mongolia, China were selected for hair sampling. There were 57 residents ( 30 females and 27 males) living in the vicinity of the Bayan Obo MA and 32 residents ( 13 females and 19 males) living in NMA. The NMA are located in the western part of Baotou City, which is approximately $200 \mathrm{~km}$ away from the Bayan Obo MA. The residents in NMA were minimally influenced by pollutants derived from the Bayan Obo mine. All of the residents investigated agreed to participate in this study and were informed that their hair will be used for chemical element determination. All hair samples were cut and collected from the occipital region of the head with scissors to reduce the influence of potential exogenous contamination. Next, the samples were respectively stored in labeled paper envelopes for further analysis.

\subsection{Analysis methods}

All reagents were of analytical reagent grade or chromatographic grade. For the dilution and washing, high-purity deionized water provided by a Milli-Q Plus filter apparatus (Millipore, MA, USA) was used. All instruments contacting the samples were prewashed using a $5 \%$ nitric acid solution.

The individual hair samples were washed with a detergent solution ( $2 \%$ non-ionic liquid detergent) and flushed with sufficient deionized water to remove exogenous matter. The washed samples were individually placed in glass beakers and dried for $10 \mathrm{~h}$ at $65^{\circ} \mathrm{C}$ in a drying oven. The samples were then weighed. The dried hair sample was cut into small pieces of $0.5-1 \mathrm{~cm}$ length. Approximately $0.2 \mathrm{~g}$ of each hair sample was weighed and then digested with $3 \mathrm{ml}$ concentrated nitric acid for $24 \mathrm{~h}$ in Teflon vessels at room temperature. The samples were further digested and heated at $100 \pm 5^{\circ} \mathrm{C}$ until no residue remained in the solution. After digestion, the solutions were cooled to room temperature and diluted with demineralized water to reach a volume of $25 \mathrm{ml}$. Human hair certified reference material (GBW07601) from the National Research Center for Standard Materials (Beijing, China) and a reagent blank were digested following the identical procedures for QC/QA purposes.

The 21 elements ( $\mathrm{Ag}, \mathrm{Al}, \mathrm{As}, \mathrm{Ba}, \mathrm{Bi}, \mathrm{Cd}, \mathrm{Co}, \mathrm{Cr}, \mathrm{Cs}, \mathrm{Cu}, \mathrm{Ga}, \mathrm{Li}, \mathrm{Mn}$, $\mathrm{Mo}, \mathrm{Ni}, \mathrm{Pb}, \mathrm{Rb}, \mathrm{Se}, \mathrm{Tl}, \mathrm{U}$ and $\mathrm{V}$ ) were measured by inductively coupled plasma mass spectrometry (ICP-MS, Perkin-Elmer, Elan 6100 DRC-e) after the addition of Re-Sc-Y as internal standards, and Ca, $\mathrm{Mg}$, Fe and $\mathrm{Zn}$ were measured by an inductively coupled plasma optical emission spectrometer (ICP-OES, PE, USA) at the Institute of Geographic Sciences and Natural Resources Research, Chinese Academy of Sciences, in Beijing, China. For the As, Cr, Se and V, the ICP-MS was operated in the DRC (Dynamic Reaction Cell) mode with $\mathrm{CH}_{4}$ as the reaction gas. For analytical precision, the corresponding relative standard deviation (RSD) values of all element concentrations measured in the reference material were found to be less than $5 \%$.

\subsection{Statistical analysis}

Shapiro-Wilk tests were performed to study the normal distribution for each element in the hair samples. The statistical significance of the data was computed by a one-way analysis of variance (ANOVA). All statistical analyses were performed using SPSS 20.0. The statistical significance was set at $p<0.01$ and $p<0.05$. 


\section{Results and discussion}

\subsection{Levels of elements in the hair of residents}

The levels of 25 elements in hair samples of females from the Bayan Obo MA and NMA are summarized in Table 1. According to Table 1 , the mean concentrations of the determined elements in the hair of females from MA were higher than those from NMA except for $\mathrm{Ag}, \mathrm{Al}, \mathrm{Cd}, \mathrm{Cu}, \mathrm{Pb}, \mathrm{Tl}, \mathrm{Rb}$ and As. The most abundant mean concentrations were found for $\mathrm{Ca}, \mathrm{Mg}$ and $\mathrm{Zn}$, with concentrations exceeding $100 \mathrm{mg} / \mathrm{kg}$, followed by $\mathrm{Fe}$ and $\mathrm{Al}$, which exhibited typical values of $62.82 \mathrm{mg} / \mathrm{kg}$ and $21.27 \mathrm{mg} / \mathrm{kg}$, respectively. Other elements with concentrations greater than $1 \mathrm{mg} / \mathrm{kg}$ were, in order of abundance, $\mathrm{Ba}>\mathrm{Cu}>\mathrm{Cr}>\mathrm{Pb}>\mathrm{Mn}$. Mean concentrations below $1 \mathrm{mg} / \mathrm{kg}$ were found for all the remaining elements. More precisely, the contents of the elements in the studied hair samples decreased in the following order: $\mathrm{Ca}>\mathrm{Mg}>\mathrm{Zn}>\mathrm{Fe}>\mathrm{Al}>\mathrm{Ba}>\mathrm{Cu}>\mathrm{Cr}>\mathrm{Pb}>\mathrm{Mn}>\mathrm{Ni}>\mathrm{Ag}>\mathrm{Co}>\mathrm{U}>\mathrm{Se}>$ $\mathrm{Bi}>\mathrm{Ga}>\mathrm{V}>\mathrm{Mo}>\mathrm{Cd}>\mathrm{Li}>\mathrm{As}>\mathrm{Rb}>\mathrm{Cs}>\mathrm{Tl}$. In hair of the females from MA, as shown by the coefficients of variation (CV) ranging from $37.39 \%$ (Ga) to $229.40 \%$ (Bi), a great variability for many of the elements was observed. High CVs exceeding $100 \%$ were found for $\mathrm{Ag}, \mathrm{Al}, \mathrm{Cd}, \mathrm{Co}, \mathrm{Ni}, \mathrm{Bi}$ and $\mathrm{As}$.

The levels of 25 elements in hair samples of males collected in MA and NMA are summarized in Table 2. The results showed that the mean concentrations of the determined elements in the hair of males from MA were higher than those from NMA except for $\mathrm{Ba}, \mathrm{Cr}, \mathrm{Se}, \mathrm{Ca}, \mathrm{Mg}$ and $\mathrm{Zn}$. The highest mean concentrations were also found for $\mathrm{Ca}, \mathrm{Mg}$ and $\mathrm{Zn}$, with concentrations exceeding $100 \mathrm{mg} / \mathrm{kg}$, followed by $\mathrm{Fe}, \mathrm{Al}$ and $\mathrm{Cu}$, which exhibited mean concentrations higher than $10 \mathrm{mg} / \mathrm{kg}$. The other elements with concentrations greater than $1 \mathrm{mg} / \mathrm{kg}$ were, in order of abundance, $\mathrm{Pb}>\mathrm{Ba}>\mathrm{Cr}>\mathrm{Ag}>\mathrm{Mn}$. The mean concentrations for the elements in MA were of the following rank order: $\mathrm{Ca}>\mathrm{Mg}>\mathrm{Zn}>\mathrm{Fe}>\mathrm{Al}>\mathrm{Cu}>\mathrm{Pb}>\mathrm{Ba}>\mathrm{Cr}>\mathrm{Ag}>\mathrm{Mn}>\mathrm{Ni}>\mathrm{Se}>\mathrm{V}>\mathrm{As}>$ $\mathrm{Ga}>\mathrm{Cd}>\mathrm{Mo}>\mathrm{U}>\mathrm{Li}>\mathrm{Co}>\mathrm{Rb}>\mathrm{Bi}>\mathrm{Cs}>\mathrm{Tl}$. The highest value of $\mathrm{CV}$ was found for $\mathrm{Ag}$ (305\%), followed by $\mathrm{Ni}, \mathrm{Bi}, \mathrm{Pb}, \mathrm{Zn}$ and $\mathrm{Cd}$, with CVs higher than $100 \%$.

The effect of living area on the concentration levels of the elements in hair of males and females was evaluated (Table 3). As shown in Table 3, the majority of the mean concentrations of the elements (including Ag, Al, Ba, Cd, Co, Li, Mn, Ni, Pb, Tl, V, Cs, Ga, $\mathrm{Rb}, \mathrm{U}, \mathrm{Bi}, \mathrm{Mo}, \mathrm{As}, \mathrm{Ca}, \mathrm{Fe}, \mathrm{Mg}$ and $\mathrm{Zn}$ ) in MA were higher than those in NMA, whereas the concentrations of $\mathrm{Cr}, \mathrm{Cu}$ and $\mathrm{Se}$ in MA were slightly lower than those in NMA.

The results showed that the mean concentrations of the target elements in human hair from MA were mainly higher than those in NMA, indicating possible exposure to higher concentrations of pollutants in the environment (water, air and soil) in MA. Elevated target element concentrations in hair were associated with the mining and smelting activities which discharged large amounts of pollutants through three wastes (waste gas, waste water, industrial residue) into the environment. Therefore, residents in MA were exposed to higher levels of pollutant concentrations, and the target elements accumulated in their body through ingestion, inhalation, and dermal contact. Moreover, elements can be transmitted from the environment into the food chain, increasing the accumulation of target elements in humans. Consequently, higher amounts of target elements accumulated in humans living in MA.

Moreover, in hair samples from females, significant differences $(p<0.01)$ in the concentration levels between MA and NMA were found for As, $\mathrm{U}$ and $\mathrm{Tl}$ (Table 3 ). Statistical differences (at $p<0.05$ ) in the concentration levels between the two study sites were observed for $\mathrm{Mg}$ and $\mathrm{Zn}$. For the hair samples from males at $p<0.01, \mathrm{Tl}$ and As exhibited significant differences in the concentration levels between the two study sites; additionally, $\mathrm{Cd}, \mathrm{Pb}$ and $\mathrm{U}$ were found to be significantly different at $p<0.05$. The average concentrations of $\mathrm{Tl}, \mathrm{Cd}$ and $\mathrm{Pb}$ found in the hair of males from MA were more than two times higher than in NMA.

Arsenic is a ubiquitous element with strong toxicity and carcinogenic effects. It is reported that arsenic ranks 20th in abundance in the earth's crust, 14th in the seawater, and 12th in the human body (Robert, 1975). The mean concentration of arsenic in the hair from males in MA was significantly higher than in NMA. The elevated levels of As in MA could result from the exposure to mining activities, which is one of the main sources of arsenic contamination (Mandal and Suzuki, 2002). Therefore, the exposure of the local population to arsenic in MA deserves future attention.

Uranium has chemical and radiological properties that have made it toxic to humans and the environment at sufficiently high levels (Keith et al., 2015). The Bayan Obo mine is a REE-Nb-Fe ore deposit with 0.001 percent uranium. The uranium level of hair in MA was observed to be higher than that in NMA. The U level of hair $(0.26 \mathrm{mg} / \mathrm{kg})$ from MA was approximately 10 times greater than that found in the hair from people living in Antillo and Fiumedinisi (Sicily), two small towns in metalliferous districts with several old abandoned mines of $\mathrm{Cu}, \mathrm{Zn}$, etc., (Dongarrà et al., 2012), and approximately 25 times higher than that from people living in the Ljubljana area of Central Slovenia (Byrne and Benedik, 1991).

Although the area of residence had been described as a factor that affects the presence of trace elements in human hair (Sukumar, 2002), the metabolic basis of how it occurs remains unknown. This current lack of knowledge on the toxicokinetics of excretion of trace elements through hair complicates the study. In addition, several factors (including environmental, nutritional and socioeconomic ones) (Llobet et al., 1998; Özden et al., 2007) may be involved but cannot be discussed in this study because of limitations of the design.

\subsection{Multivariate analysis}

To reduce the dimensionality of the linearly correlated data and to identify possible sources of trace elements in hair samples, a Principal Component Analysis (PCA) was performed to group the chemical variables into a smaller number of independent factors whereas preserving most of the original information, accounting for the maximum explainable variance of original data. We investigated the possibility of using PCA to further study the inter-relationship between the hair element levels and discuss the potential sources. The results of the PCA are shown in the loading plot (Fig. 1). Three Principal Components emerged and together accounted for almost $58.6 \%$ of the total variance. During the first iterations, $\mathrm{Cu}$ and $\mathrm{Bi}$ had low loadings $(<0.5)$; Ni showed a complex structure (loading $>0.4$ on more than one component) and was therefore deemed not suitable for PCA and removed from the analysis. Component 1 was dominated by $\mathrm{Al}, \mathrm{Cr}, \mathrm{Li}, \mathrm{Tl}, \mathrm{V}, \mathrm{Cs}, \mathrm{Rb}, \mathrm{Mo}$, Se and Fe, accounting for $26.0 \%$ of the total variance. The second component, which explained almost $21.7 \%$ of the total variance, included Ba, Co, Ga, U, Zn, Ca, Mg and As. The third component, with a variance of $10.9 \%$, was positively correlated with $\mathrm{Ag}, \mathrm{Cd}, \mathrm{Mn}$ and $\mathrm{Pb}$.

Samples from MA and NMA typically formed distinct groups (Fig. 2), with males and females properly separated for MA, but not for NMA. This grouping was a consequence of the multiple univariate differences previously observed between MA and NMA, and between males and females in terms of chemical profiles.

However, source identification using human hair has not been rigorously tested for suitability because hair is a different medium than traditional investigated materials such as soil or air particulates. Select attempts have employed a multivariate analysis to identify sources of hair trace elements in general populations (Nowak and Chmielnicka, 2000; Varrica et al., 2014b; Wang et al., 
Table 1

Levels of elements in hair samples of females $(\mathrm{mg} / \mathrm{kg})$.

\begin{tabular}{|c|c|c|c|c|c|c|c|c|c|c|}
\hline \multirow[t]{2}{*}{ Element } & \multicolumn{4}{|l|}{$\operatorname{MA}(N=30)$} & \multirow[t]{2}{*}{$\mathrm{CV}$} & \multicolumn{4}{|l|}{$\operatorname{NMA}(N=13)$} & \multirow[t]{2}{*}{$\mathrm{CV}$} \\
\hline & $\mathrm{AM} \pm \mathrm{STD}$ & GM & Median & Range & & $\mathrm{AM} \pm \mathrm{STD}$ & GM & Median & Range & \\
\hline $\mathrm{Ag}$ & $0.61 \pm 0.18$ & 0.21 & 0.15 & $0.025-3.51$ & 159.68 & $1.15 \pm 0.39$ & 0.51 & 0.51 & $0.033-4.44$ & 122.01 \\
\hline Al & $21.27 \pm 5.40$ & 11.89 & 13.59 & $0.10-164.48$ & 139.07 & $23.58 \pm 3.95$ & 20.34 & 22.69 & $9.02-56.82$ & 60.38 \\
\hline $\mathrm{Ba}$ & $9.87 \pm 0.72$ & 8.90 & 10.04 & $1.63-20.25$ & 39.96 & $9.13 \pm 2.11$ & 6.60 & 6.99 & $1.87-25.45$ & 83.42 \\
\hline $\mathrm{Cd}$ & $0.062 \pm 0.014$ & 0.041 & 0.038 & $0.0079-0.40$ & 120.56 & $0.11 \pm 0.045$ & 0.055 & 0.045 & $0.0087-0.58$ & 148.97 \\
\hline Co & $0.49 \pm 0.19$ & 0.15 & 0.094 & $0.015-4.78$ & 207.86 & $0.092 \pm 0.018$ & 0.074 & 0.074 & $0.024-0.25$ & 68.88 \\
\hline $\mathrm{Cr}$ & $2.41 \pm 0.27$ & 2.14 & 1.95 & $0.82-7.38$ & 60.77 & $2.15 \pm 0.44$ & 1.89 & 1.72 & $1.16-7.36$ & 74.23 \\
\hline $\mathrm{Cu}$ & $9.07 \pm 0.73$ & 8.31 & 8.40 & $3.16-18.55$ & 43.80 & $12.23 \pm 2.84$ & 10.39 & 8.96 & $5.63-45.49$ & 83.82 \\
\hline $\mathrm{Li}$ & $0.058 \pm 0.0069$ & 0.051 & 0.048 & $0.017-0.21$ & 65.45 & $0.054 \pm 0.0094$ & 0.047 & 0.051 & $0.019-0.16$ & 62.95 \\
\hline Mn & $1.28 \pm 0.16$ & 1.05 & 0.99 & $0.29-4.17$ & 68.03 & $1.03 \pm 0.12$ & 0.93 & 1.11 & $0.28-1.78$ & 41.30 \\
\hline $\mathrm{Ni}$ & $0.93 \pm 0.19$ & 0.64 & 0.59 & $0.10-4.84$ & 111.06 & $0.62 \pm 0.12$ & 0.47 & 0.59 & $0.13-1.43$ & 68.55 \\
\hline $\mathrm{Pb}$ & $2.36 \pm 0.37$ & 1.71 & 1.90 & $0.29-8.80$ & 86.48 & $3.25 \pm 0.77$ & 2.43 & 2.21 & $0.34-11.33$ & 85.05 \\
\hline $\mathrm{Tl}$ & $0.0011 \pm 0.00016$ & 0.00087 & 0.00082 & $0.00033-0.0042$ & 80.72 & $0.0025 \pm 0.00046$ & 0.0019 & 0.0021 & $0.00036-0.005$ & 67.54 \\
\hline V & $0.17 \pm 0.015$ & 0.16 & 0.16 & $0.051-0.41$ & 47.59 & $0.17 \pm 0.02054$ & 0.15 & 0.17 & $0.088-0.28$ & 43.49 \\
\hline Cs & $0.0029 \pm 0.00040$ & 0.0024 & 0.0023 & $0.0011-0.012$ & 76.00 & $0.0028 \pm 0.00038$ & 0.0026 & 0.0025 & $0.0016-0.0067$ & 48.66 \\
\hline $\mathrm{Ga}$ & $0.21 \pm 0.015$ & 0.20 & 0.21 & $0.042-0.41$ & 37.39 & $0.21 \pm 0.043$ & 0.16 & 0.17 & $0.049-0.54$ & 74.79 \\
\hline $\mathrm{Rb}$ & $0.043 \pm 0.0061$ & 0.036 & 0.031 & $0.020-0.16$ & 77.34 & $0.046 \pm 0.0046$ & 0.044 & 0.044 & $0.027-0.092$ & 36.29 \\
\hline $\mathrm{U}$ & $0.41 \pm 0.051$ & 0.34 & 0.33 & $0.12-1.49$ & 67.69 & $0.12 \pm 0.033$ & 0.087 & 0.074 & $0.038-0.44$ & 102.32 \\
\hline $\mathrm{Bi}$ & $0.24 \pm 0.20$ & 0.021 & 0.017 & $0.0017-6.04$ & 229.40 & $0.030 \pm 0.0091$ & 0.018 & 0.020 & $0.0023-0.12$ & 108.44 \\
\hline Mo & $0.065 \pm 0.0067$ & 0.057 & 0.058 & $0.020-0.20$ & 56.27 & $0.061 \pm 0.01$ & 0.052 & 0.059 & $0.018-0.16$ & 58.76 \\
\hline As & $0.045 \pm 0.011$ & 0.029 & 0.025 & $0.0069-0.24$ & 145.22 & $0.12 \pm 0.037$ & 0.066 & 0.051 & $0.013-0.43$ & 113.32 \\
\hline Se & $0.32 \pm 0.057$ & 0.24 & 0.26 & $0.027-1.48$ & 98.11 & $0.24 \pm 0.057$ & 0.16 & 0.18 & $0.028-0.77$ & 87.88 \\
\hline $\mathrm{Ca}$ & $6036.86 \pm 572.99$ & 4875.76 & 6114.49 & $637.50-11698.47$ & 51.99 & $3894.39 \pm 1021.88$ & 2203.35 & 2158.90 & $357.6-10465.1$ & 94.61 \\
\hline $\mathrm{Fe}$ & $62.82 \pm 10.26$ & 51.38 & 43.01 & $23.28-318.56$ & 89.48 & $52.32 \pm 8.17$ & 47.22 & 40.54 & $28.33-138.87$ & 56.28 \\
\hline $\mathrm{Mg}$ & $745.43 \pm 71.39$ & 622.63 & 711.03 & $97.98-1530.64$ & 52.45 & $447.40 \pm 104.16$ & 295.73 & 274.52 & $56.56-1271$ & 83.94 \\
\hline $\mathrm{Zn}$ & $281.67 \pm 41.70$ & 207.53 & 175.65 & $37.17-899.38$ & 81.08 & $130.97 \pm 15.98$ & 119.47 & 123.85 & $55.07-254.15$ & 44.00 \\
\hline
\end{tabular}

AM, arithmetic mean.

STD, standard deviation.

GM, geometrical mean.

$\mathrm{CV}$, coefficients of variation.

2009), although those studies did not discuss the rigidity and reliability of the methods used. Additionally, the uptake mechanisms and pharmacokinetics might alter the concentration trends of the elements in hair of each individual from what is observed in the surrounding environment, complicating the apportionment of the source. The results from the multivariate analyses in this study can therefore be interpreted in three ways; that exogenous sources dominated the observations (reflecting external environmental sources). Long term occupational exposure would consequently result in the incorporation of exogenous contaminations into the

Table 2

Levels of elements in hair samples of males $(\mathrm{mg} / \mathrm{kg})$.

\begin{tabular}{|c|c|c|c|c|c|c|c|c|c|c|c|c|}
\hline \multirow[t]{2}{*}{ Element } & \multicolumn{5}{|l|}{ MA } & \multirow[t]{2}{*}{$\mathrm{CV} \%$} & \multicolumn{5}{|c|}{ NMA } & \multirow[t]{2}{*}{$\mathrm{CV} \%$} \\
\hline & $N$ & $\mathrm{AM} \pm \mathrm{STD}$ & GM & Median & Range & & $N$ & $\mathrm{AM} \pm \mathrm{STD}$ & GM & Median & Range & \\
\hline $\mathrm{Ag}$ & 27 & $2.32 \pm 1.36$ & 0.40 & 0.29 & $0.045-36.23$ & 305.00 & 19 & $0.14 \pm 0.031$ & 0.088 & 0.073 & $0.012-0.57$ & 98.78 \\
\hline $\mathrm{Al}$ & 27 & $31.25 \pm 4.68$ & 20.99 & 27.85 & $1.42-86.43$ & 77.82 & 19 & $22.8 \pm 5.2$ & 11.23 & 13.41 & $0.051-80.02$ & 99.38 \\
\hline $\mathrm{Ba}$ & 27 & $6.17 \pm 0.68$ & 5.25 & 6.01 & $1.49-17.59$ & 57.42 & 19 & $6.2 \pm 0.84$ & 5.21 & 5.30 & $1.93-15.42$ & 58.99 \\
\hline $\mathrm{Cd}$ & 27 & $0.11 \pm 0.023$ & 0.067 & 0.060 & $0.0068-0.57$ & 108.29 & 19 & $0.046 \pm 0.01$ & 0.031 & 0.031 & $0.0062-0.17$ & 98.01 \\
\hline Co & 27 & $0.075 \pm 0.009$ & 0.060 & 0.072 & $0.010-0.19$ & 62.42 & 19 & $0.073 \pm 0.015$ & 0.053 & 0.048 & $0.015-0.27$ & 90.62 \\
\hline $\mathrm{Cr}$ & 25 & $2.97 \pm 2.26$ & 2.42 & 1.91 & $1.27-10.60$ & 84.06 & 19 & $3.23 \pm 0.53$ & 2.66 & 2.24 & $1.39-8.68$ & 71.49 \\
\hline $\mathrm{Cu}$ & 27 & $10.24 \pm 1.36$ & 9.10 & 8.54 & $2.43-43.52$ & 69.08 & 19 & $8.82 \pm 0.51$ & 8.60 & 8.10 & $5.92-14.97$ & 25.42 \\
\hline $\mathrm{Li}$ & 27 & $0.08 \pm 0.013$ & 0.062 & 0.059 & $0.018-0.32$ & 84.12 & 19 & $0.07 \pm 0.013$ & 0.054 & 0.041 & $0.020-0.25$ & 83.53 \\
\hline Mn & 27 & $2.16 \pm 0.34$ & 1.39 & 1.27 & 0.12-6.05 & 82.38 & 19 & $1.37 \pm 0.27$ & 1.00 & 1.00 & $0.21-4.86$ & 85.39 \\
\hline $\mathrm{Ni}$ & 27 & $0.84 \pm 0.22$ & 0.48 & 0.46 & $0.079-5.11$ & 133.08 & 19 & $0.41 \pm 0.077$ & 0.32 & 0.29 & $0.076-1.31$ & 80.84 \\
\hline $\mathrm{Pb}$ & 27 & $6.5 \pm 1.39$ & 3.86 & 3.34 & $0.35-31.11$ & 111.31 & 19 & $2.56 \pm 0.69$ & 1.52 & 1.92 & $0.2-13.33$ & 118.19 \\
\hline $\mathrm{Tl}$ & 27 & $0.0045 \pm 0.0006$ & 0.0035 & 0.0041 & $0.0006-0.010$ & 64.28 & 19 & $0.0022 \pm 0.0002$ & 0.0019 & 0.0019 & $0.0008-0.0043$ & 48.86 \\
\hline V & 27 & $0.2 \pm 0.018$ & 0.17 & 0.20 & $0.047-0.42$ & 47.79 & 19 & $0.15 \pm 0.034$ & 0.11 & 0.088 & $0.047-0.58$ & 98.35 \\
\hline Cs & 27 & $0.005 \pm 0.0008$ & 0.0035 & 0.0030 & $0.001-0.02$ & 89.72 & 19 & $0.0036 \pm 0.001$ & 0.0026 & 0.0019 & $0.001-0.02$ & 118.31 \\
\hline $\mathrm{Ga}$ & 27 & $0.16 \pm 0.016$ & 0.14 & 0.15 & $0.041-0.39$ & 53.46 & 19 & $0.15 \pm 0.021$ & 0.12 & 0.12 & $0.05-0.39$ & 60.96 \\
\hline $\mathrm{Rb}$ & 27 & $0.075 \pm 0.01$ & 0.063 & 0.062 & $0.019-0.26$ & 68.11 & 19 & $0.058 \pm 0.012$ & 0.045 & 0.041 & $0.018-0.25$ & 92.79 \\
\hline U & 27 & $0.088 \pm 0.017$ & 0.070 & 0.067 & $0.025-0.49$ & 99.25 & 19 & $0.18 \pm 0.049$ & 0.12 & 0.10 & $0.043-0.90$ & 117.80 \\
\hline $\mathrm{Bi}$ & 27 & $0.022 \pm 0.0055$ & 0.014 & 0.013 & $0.0042-0.12$ & 132.67 & 19 & $0.01 \pm 0.0023$ & 0.0078 & 0.0070 & $0.0022-0.049$ & 99.55 \\
\hline Mo & 27 & $0.095 \pm 0.013$ & 0.080 & 0.075 & $0.026-0.35$ & 72.36 & 19 & $0.071 \pm 0.0079$ & 0.065 & 0.059 & $0.035-0.14$ & 48.38 \\
\hline As & 27 & $0.18 \pm 0.13$ & 0.12 & 0.15 & $0.014-0.58$ & 81.55 & 19 & $0.067 \pm 0.013$ & 0.045 & 0.051 & $0.0054-0.24$ & 87.71 \\
\hline Se & 27 & $0.43 \pm 0.051$ & 0.35 & 0.34 & $0.033-1.22$ & 61.60 & 19 & $0.52 \pm 0.069$ & 0.43 & 0.44 & $0.062-1.16$ & 58.26 \\
\hline $\mathrm{Ca}$ & 27 & $1882.65 \pm 308.09$ & 1409.75 & 1512.06 & $372.46-6901.91$ & 85.03 & 19 & $2460.79 \pm 447.67$ & 1857.64 & 1744.34 & 474.99-7691.86 & 79.30 \\
\hline $\mathrm{Fe}$ & 27 & $86.12 \pm 15.02$ & 66.51 & 58.60 & 19.75-390.82 & 90.64 & 19 & $66.21 \pm 13.42$ & 51.61 & 42.03 & 26.76-251.85 & 88.35 \\
\hline $\mathrm{Mg}$ & 27 & $300.56 \pm 41.99$ & 233.03 & 249.28 & $51.47-940.64$ & 72.59 & 19 & $313.99 \pm 40.43$ & 264.94 & 317.55 & $67.72-790.58$ & 56.13 \\
\hline $\mathrm{Zn}$ & 27 & $145.99 \pm 30.71$ & 120.08 & 122.67 & $54.46-928.07$ & 109.29 & 19 & $157.19 \pm 14.46$ & 146.27 & 149.70 & $71.49-317.43$ & 40.11 \\
\hline
\end{tabular}

$\mathrm{AM}$, arithmetic mean.

STD, standard deviation.

GM, geometrical mean.

$\mathrm{CV}$, coefficients of variation. 
Table 3

The effect of the area of residence on the content of elements in scalp hair.

\begin{tabular}{|c|c|c|c|c|}
\hline \multirow[t]{2}{*}{ Element } & \multicolumn{2}{|l|}{$\mathrm{AM} \pm \mathrm{STD}$} & \multicolumn{2}{|c|}{$t$-Value (residence differences) } \\
\hline & MA & NMA & Females & Males \\
\hline $\mathrm{Ag}$ & $1.42 \pm 0.65$ & $0.55 \pm 0.18$ & -1.476 & 1.34 \\
\hline $\mathrm{Al}$ & $26.00 \pm 3.63$ & $23.12 \pm 3.43$ & -0.267 & 1.193 \\
\hline $\mathrm{Ba}$ & $8.12 \pm 0.55$ & $7.39 \pm 1.01$ & 0.425 & -0.025 \\
\hline $\mathrm{Cd}$ & $0.084 \pm 0.013$ & $0.072 \pm 0.020$ & -1.344 & $2.180^{*}$ \\
\hline Co & $0.29 \pm 0.10$ & $0.081 \pm 0.011$ & 1.396 & 0.144 \\
\hline $\mathrm{Cr}$ & $2.66 \pm 0.25$ & $2.80 \pm 0.37$ & 0.516 & -0.706 \\
\hline $\mathrm{Cu}$ & $9.62 \pm 0.75$ & $10.21 \pm 1.20$ & -1.467 & 0.839 \\
\hline $\mathrm{Li}$ & $0.068 \pm 0.0072$ & $0.063 \pm 0.0088$ & 0.344 & 0.527 \\
\hline Mn & $1.70 \pm 0.19$ & $1.23 \pm 0.17$ & 0.992 & 1.689 \\
\hline $\mathrm{Ni}$ & $0.89 \pm 0.14$ & $0.50 \pm 0.068$ & 1.024 & 1.61 \\
\hline $\mathrm{Pb}$ & $4.32 \pm 0.73$ & $2.84 \pm 0.51$ & -1.171 & $2.236^{*}$ \\
\hline $\mathrm{Tl}$ & $0.0027 \pm 0.00035$ & $0.0023 \pm 0.00023$ & $-3.497^{* *}$ & $3.32^{* *}$ \\
\hline V & $0.18 \pm 0.012$ & $0.16 \pm 0.022$ & 0.147 & 1.249 \\
\hline Cs & $0.0037 \pm 0.00044$ & $0.0033 \pm 0.00060$ & 0.055 & 0.798 \\
\hline $\mathrm{Ga}$ & $0.19 \pm 0.011$ & $0.17 \pm 0.022$ & 0.148 & 0.437 \\
\hline $\mathrm{Rb}$ & $0.058 \pm 0.0060$ & $0.053 \pm 0.0075$ & -0.268 & 1.079 \\
\hline $\mathrm{U}$ & $0.26 \pm 0.035$ & $0.16 \pm 0.032$ & $3.647^{* *}$ & $-2.033^{*}$ \\
\hline $\mathrm{Bi}$ & $0.14 \pm 0.11$ & $0.018 \pm 0.0042$ & 0.697 & 1.643 \\
\hline Mo & $0.079 \pm 0.0074$ & $0.067 \pm 0.0061$ & 0.361 & 1.37 \\
\hline As & $0.10 \pm 0.016$ & $0.088 \pm 0.017$ & -2.718 *** & $3.033^{* *}$ \\
\hline Se & $0.37 \pm 0.039$ & $0.40 \pm 0.053$ & 0.893 & -1 \\
\hline $\mathrm{Ca}$ & $4069.08 \pm 432.66$ & $3043.19 \pm 499.30$ & 1.951 & -1.102 \\
\hline $\mathrm{Fe}$ & $73.86 \pm 8.99$ & $60.57 \pm 8.61$ & 0.634 & 0.94 \\
\hline Mg & $534.70 \pm 51.55$ & $368.19 \pm 49.07$ & $2.322^{*}$ & -0.222 \\
\hline $\mathrm{Zn}$ & $217.40 \pm 27.63$ & $146.54 \pm 10.85$ & $2.332^{*}$ & -0.29 \\
\hline
\end{tabular}

AM, arithmetic mean.

STD, standard deviation.

${ }^{*} t$-Value is significant at $5 \%$ level.

** $t$-Value is significant at $1 \%$ level.

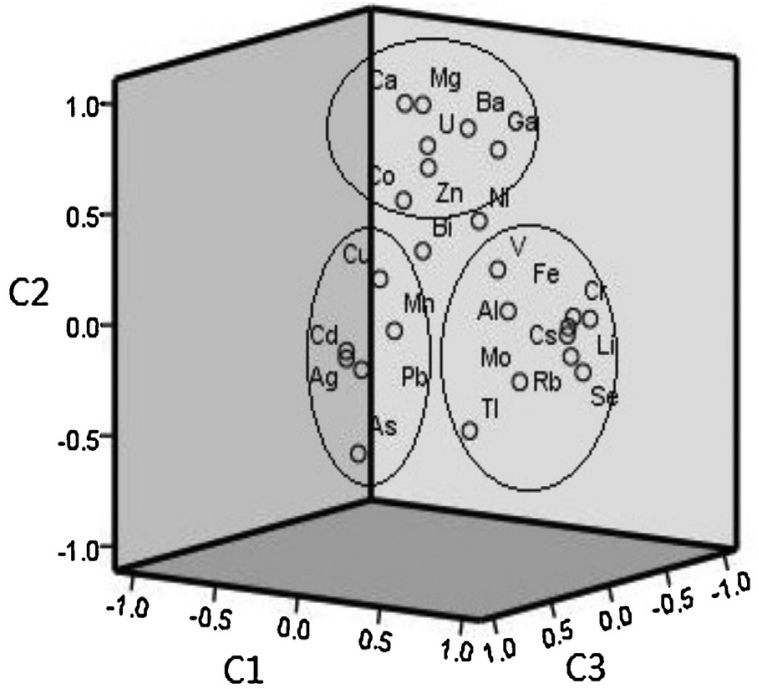

Fig. 1. Loading plot for the three principal components of elemental concentrations in hair samples. Loading plot for the three principal components of 25 elemental concentrations in hair samples. The three coordinate axes represent the loadings of each elements in three principal components ( 1 , C2 and C3) individually.

hair structure, suggesting that hair acts as a passive sampler for particulate and gaseous phase pollutants and could reflect ambient environmental or occupational conditions. The second interpretation would be that all exogenous contaminations had been removed by washing steps and therefore the levels of observations could reflect the uptake and exposure through inhalation and diet. The third explanation would be that both endogenous and exogenous facts contributed in the accumulation and it is probably the case for most observations in highly polluted areas, such as those in the present study.
Table 4

The effect of gender on the content of elements in scalp hair of residents.

\begin{tabular}{|c|c|c|}
\hline \multirow[t]{2}{*}{ Element } & \multicolumn{2}{|c|}{ Gender-related differences ( $t$-value) } \\
\hline & MA & NMA \\
\hline $\mathrm{Ag}$ & 1.314 & $3.148^{* *}$ \\
\hline $\mathrm{Al}$ & 1.382 & 0.111 \\
\hline $\mathrm{Ba}$ & $-3.711^{* *}$ & 1.457 \\
\hline $\mathrm{Cd}$ & 1.815 & 1.612 \\
\hline Co & $-2.111 *$ & 0.834 \\
\hline $\mathrm{Cr}$ & 0.663 & -1.461 \\
\hline $\mathrm{Cu}$ & 0.775 & 1.409 \\
\hline $\mathrm{Li}$ & 1.563 & -0.911 \\
\hline Mn & $2.410^{*}$ & -1.012 \\
\hline $\mathrm{Ni}$ & -0.297 & 1.544 \\
\hline $\mathrm{Pb}$ & $\mathbf{3 . 0 0 2}^{* *}$ & 0.66 \\
\hline $\mathrm{Tl}$ & $\mathbf{6 . 1 1 2}^{* *}$ & 0.592 \\
\hline V & 0.895 & 0.44 \\
\hline Cs & 2.056 & -0.654 \\
\hline Ga & $-2.495^{*}$ & 1.395 \\
\hline $\mathrm{Rb}$ & $2.786^{* *}$ & -0.779 \\
\hline $\mathrm{U}$ & $-5.784^{* *}$ & -0.964 \\
\hline $\mathrm{Bi}$ & -1.052 & $2.498^{*}$ \\
\hline Mo & $2.074^{*}$ & -0.849 \\
\hline As & $4.694^{* *}$ & 1.499 \\
\hline Se & 1.427 & $-2.914^{* * *}$ \\
\hline $\mathrm{Ca}$ & $-6.188^{* *}$ & 1.434 \\
\hline $\mathrm{Fe}$ & 1.303 & -0.788 \\
\hline $\mathrm{Mg}$ & $-5.222^{* *}$ & 1.353 \\
\hline $\mathrm{Zn}$ & $-2.572^{*}$ & -1.196 \\
\hline
\end{tabular}

\subsection{Effect of gender on the contents of elements in human hair}

The presence of gender-related differences was also evaluated on MA and NMA data (considered separately) (Table 4). According to Table 4, the hair samples from MA showed statistically significant differences between males and females $(t$-test, $p<0.05)$ for a larger number of elements (Ba, Co, Mn, Pb, Tl, Cs, Ga, Rb, U, Mo, As, Ca, Mg 


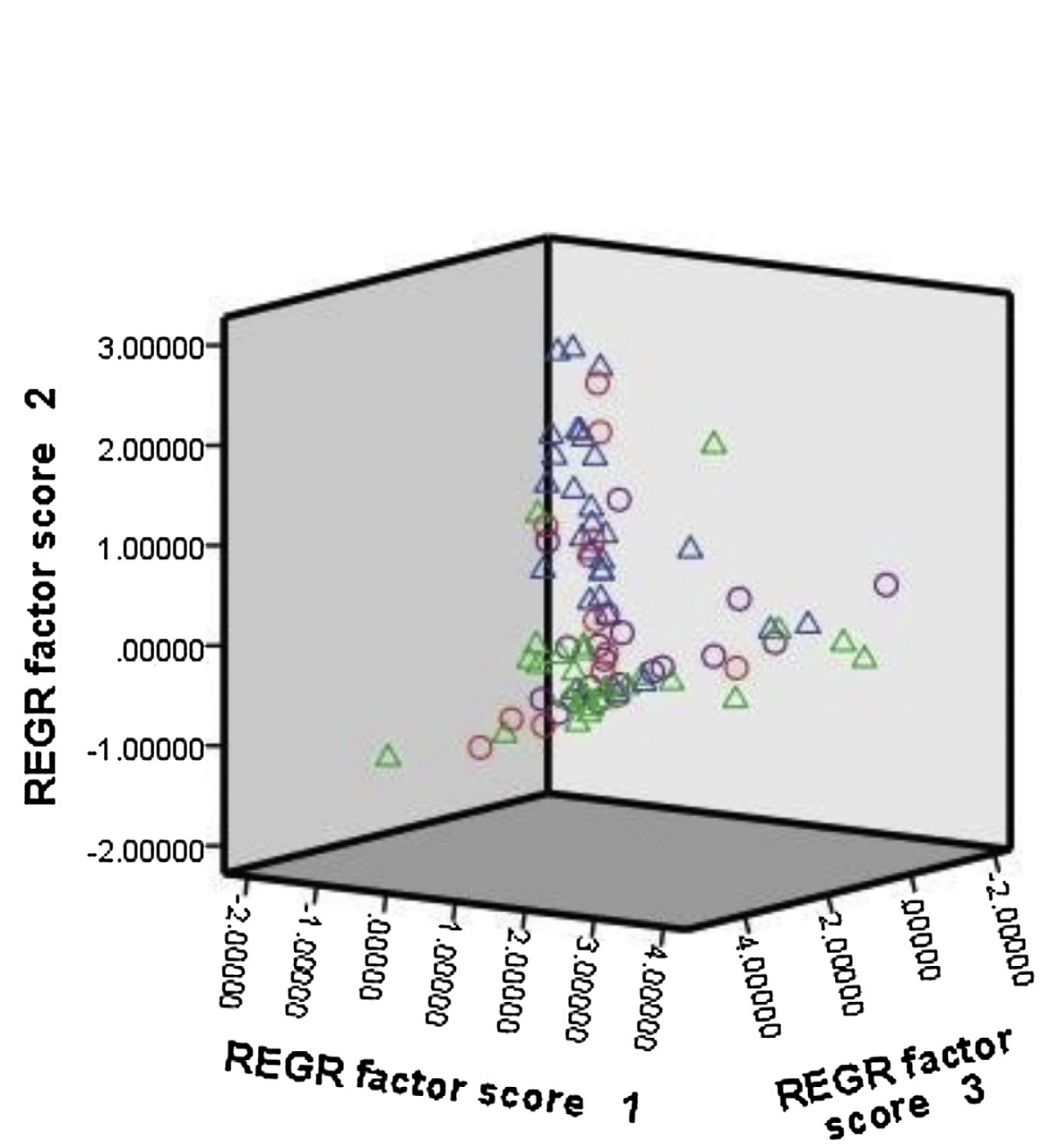

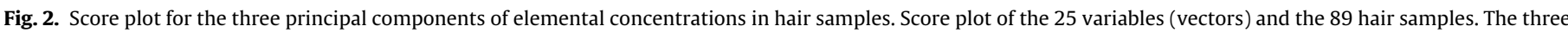

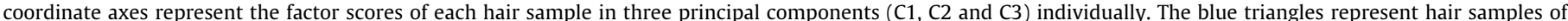

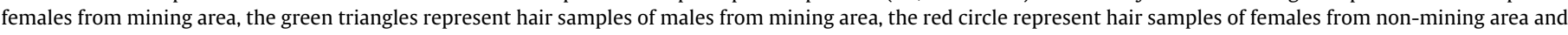

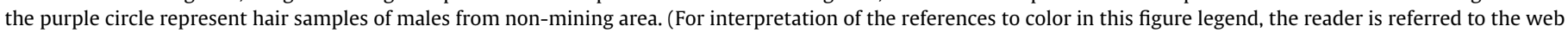
version of the article.)

and $\mathrm{Zn}$ ) than at NMA, in which only $\mathrm{Ag}, \mathrm{Bi}$ and Se were significantly different. In MA, higher concentrations in the hair of females were found for Ba, Co, Ga, U, Ca, Mg and Zn, while for Mn, Pb, Tl, Cs, Rb, Mo and As, significantly higher concentrations were found in the hair of males; as for residents in NMA, significantly higher concentrations of $\mathrm{Ag}$ and $\mathrm{Bi}$ were found in the hair of females (Table 1), whereas only the concentration of Se was significantly higher in the hair of males than that for females (Table 2).

Biological and non-biological factors may influence the response of males and females to the exposure to chemicals (Vahter et al., 2007). Significantly higher levels of Ba and $\mathrm{Zn}$ in female hair samples were reported by Dongarrà et al. (2012). Varrica et al. (2014b) also revealed that $\mathrm{Ag}, \mathrm{Ba}, \mathrm{Cd}, \mathrm{Co}, \mathrm{Cu}, \mathrm{Ni}, \mathrm{Sr}, \mathrm{U}$ and $\mathrm{Zn}$ levels in hair were significantly higher in females at Iglesias (Sardinia, Italy). However, explaining the significantly higher concentrations in the hair of females for $\mathrm{Ba}, \mathrm{Co}, \mathrm{Ga}, \mathrm{U}, \mathrm{Ca}, \mathrm{Mg}$ and $\mathrm{Zn}$ in MA remains difficult.

A different gender-related way of assimilation and detoxifying (occurring when the metal burden increases) may be invoked, but additional information and further investigation are needed to reach such a conclusion. However, this finding indicated that females could be more vulnerable to exposures to trace elements than males, particularly at higher exposure levels. A previous study reported that females seemed to have a higher risk of toxic metal exposure than males (Berglund et al., 2011), which is consistent with the finding of the present study. Furthermore, this issue also contradicts the common belief that males are more exposed to these elements than females because they spend more time outside and therefore are more exposed to trace elements from soil and dust (Freeman et al., 2004; Shalat et al., 2003). The gender difference of element contents in hair might be explained on the basis of the exposure frequencies, but the metabolism and physiological roles of elements in the two genders are also of great concern (Vahter et al., 2007).

Furthermore, according to Table 4, a larger amount of elements (14 elements) displayed significant difference in concentration based on gender in MA than in NMA (3 elements), reflecting the influence of mining activities on residents living in the vicinity. Mining activities (including mineral excavation and ore transportation) resulted in a more complex and diversified living and working environment between males and females. Simultaneously, the chances of exposure to various chemicals varied significantly. The exact mechanisms of action have not been identified. Several studies have embarked on investigating gender-related differences in response to environmental exposures. Based on the more extensive literature on the action and side-effects of therapeutic drugs (Christian, 2001; Soldin and Mattison, 2009), gender differences in the toxic effect of chemicals contacted in the working and general 
environment are to be expected. A meeting under the auspice of the Society for Women's Health Research concluded that a greater focus on interdisciplinary, hypothesis-driven research is essential to understanding potential interactions between sex and environmental exposures on health (Keitt et al., 2004). Future research needs to explore gender differences from the molecular and cellular levels to behavioral responses and should track these effects across multiple generations.

\section{Conclusions}

In the present work, human hair was studied to determine the contents of 25 trace elements. The study discovered marked differences in hair trace element concentrations of the residents living near the Bayan Obo mining area and the non-mining area. Additionally, the study compared males and females in the identical living areas. The results showed that the mean concentrations of the target elements in human hair from MA were primarily higher than that in NMA, indicating that exposure to higher concentrations of pollutants in the environment originated in mining activities, enriched soils, waters and food in MA. Additionally, the area of residence had an influence on the presence of trace elements in human hair. The hair samples from MA showed statistically significant differences between males and females for a larger number of elements than in NMA, in which only $\mathrm{Ag}, \mathrm{Bi}$ and Se were significantly different. This result reflected the influence of mining activities on residents living in the vicinity.

The results from our present study also showed that the use of hair as a noninvasive and cost-effective method could provide preliminary information on the exposure of heavy metals and toxic elements to residents in areas that were heavily contaminated from intensive mining activities. Although the findings of this survey were not intended to be diagnostic, the results provided evidence of a potential risk of adverse effects on the health of the exposed population and suggested the need to go beyond these preliminary results and to extend this approach. Further studies are recommended to evaluate the correlation between the elevated levels of contaminants in hair, blood or urine samples and adverse health effects and to further elucidate the different exposure pathways.

\section{Conflict of interest}

The authors declare that there are no conflicts of interest.

\section{Transparency document}

The Transparency document associated with this article can be found in the online version.

\section{Acknowledgments}

This work was sponsored by the Key Project of the Knowledge Innovation Program of IGSNRR (2012ZD002). We are grateful to Guiyue Chen, Jingwei Du, Yonghua Li, Jiangping Yu and Tao Liang for their sampling and analytical work during the early stage of this project.

\section{References}

Afridi, H.I., Kazi, T.G., Brabazon, D., Naher, S., 2011. Association between essential trace and toxic elements in scalp hair samples of smokers rheumatoid arthritis subjects. Sci. Total Environ. 412-413, 93-100.

Bech, J., Poschenrieder, C., Llugany, M., Barceló, J., Tume, P., Tobias, F.J., Barranzuela, J.L., Vásquez, E.R., 1997. Arsenic and heavy metal contamination of soil and vegetation around a copper mine in Northern Peru. Sci. Total Environ. 203, 83-91.

Berglund, M., Lindberg, A.-L., Rahman, M., Yunus, M., Grandér, M., Lönnerdal, B., Vahter, M., 2011. Gender and age differences in mixed metal exposure and urinary excretion. Environ. Res. 111, 1271-1279.
Burger, J., Marquez, M., Gochfeld, M., 1994. Heavy metals in the hair of opossum from Palo Verde Costa Rica. Arch. Environ. Contam. Toxicol. 27, 472-476.

Byrne, A.R., Benedik, L., 1991. Uranium content of blood, urine and hair of exposed and non-exposed persons determined by radiochemical neutron activation analysis, with emphasis on quality control. Sci. Total Environ. 107, 143-157.

Chehregani, A., Noori, M., Yazdi, H.L., 2009. Phytoremediation of heavy-metalpolluted soils: screening for new accumulator plants in Angouran mine (Iran) and evaluation of removal ability. Ecotoxicol. Environ. Saf. 72, 1349-1353.

Christian, M.S., 2001. Introduction/overview: gender-based differences in pharmacologic and toxicologic responses. Int. J. Toxicol. 20, 145-148.

Coelho, P., Costa, S., Fau-Costa, C., Costa, C., Fau-Silva, S., Silva, S., Fau-Walter, A Walter, A., Fau-Ranville, J., Ranville, J., Fau-Pastorinho, M.R., Pastorinho $\mathrm{Mr}$ Fau-Harrington, C., Harrington, C., Fau-Taylor, A., Taylor, A., Fau-Dall'Armi, V., Dall'Armi, V., Fau-Zoffoli, R., Zoffoli, R., Fau-Candeias, C., Candeias, C., Fau-da Silva, E.F., da Silva Ef Fau-Bonassi, S., Bonassi, S., Fau-Laffon, B., Laffon, B., FauTeixeira, J.P., Teixeira, J.P., 2014. Biomonitoring of several toxic metal(loid)s in different biological matrices from environmentally and occupationally exposed populations from Panasqueira mine area, Portugal. Environ. Geochem. Health 36, 255-269

Coelho, P.C.S., Teixeira, J.P.F., Gonçalves, O.N.B.S.M., 2011. Mining activities: health impacts. In: Nriagu, J.O. (Ed.), Encyclopedia of Environmental Health. Elsevier, Burlington, pp. 788-802.

Dongarrà, G., Varrica, D., Tamburo, E., D’Andrea, D., 2012. Trace elements in scalp hai of children living in differing environmental contexts in Sicily (Italy). Environ. Toxicol. Pharmacol. 34, 160-169.

Drew, L.J., Qingrun, M., Weijun, S., 1990. The Bayan Obo iron-rare-earth-niobium deposits, Inner Mongolia, China. Lithos 26, 43-65.

Elinder, C.-G., Gerhardsson, L., Oberdoerster, G., 1988. Biological monitoring of toxic metals - overview. In: Clarkson, T., Friberg, L., Nordberg, G., Sager, P. (Eds.) Biological Monitoring of Toxic Metals. Springer, US, pp. 1-71.

Foo, S.C., Khoo, N.Y., Heng, A., Chua, L.H., Chia, S.E., Ong, C.N., Ngim, C.H., Jeyaratnam, J., 1993. Metals in hair as biological indices for exposure. Int. Arch. Occup. Environ. Heath 65, S83-S86.

Freeman, N.C.G., Hore, P., Black, K., Jimenez, M., Sheldon, L., Tulve, N., Lioy, P.J. 2004. Contributions of children's activities to pesticide hand loadings following residential pesticide application. J. Expo. Anal. Environ. Epidemiol. 15, 81-88.

Gil, F., Hernández, A.F., Márquez, C., Femia, P., Olmedo, P., López-Guarnido, O., Pla, A., 2011. Biomonitorization of cadmium, chromium, manganese, nickel and lead in whole blood, urine, axillary hair and saliva in an occupationally exposed population. Sci. Total Environ. 409, 1172-1180.

Guo, W., Zhao, R., Zhao, W., Fu, R., Guo, J., Bi, N., Zhang, J., 2013. Effects of arbuscular mycorrhizal fungi on maize (Zea mays L.) and sorghum (Sorghum bicolor L. Moench) grown in rare earth elements of mine tailings. Appl. Soil Ecol. 72, 85-92.

Keith, L.S., Faroon, O.M., Fowler, B.A., 2015. Uranium. In: Nordberg, G.F.N.A.F. (Ed.), Handbook on the Toxicology of Metals. , fourth ed. Academic Press, San Diego, pp. 1307-1345 (Chapter 59).

Keitt, S.K., Fagan, T.F., Marts, S.A., 2004. Understanding sex differences in environmental health: a thought leaders' roundtable. Environ. Health Perspect. 112, 604-609.

Kronstrand, R., Forstberg-Peterson, S., Fau-Kagedal, B., Kagedal, B., Fau-Ahlner, J., Ahlner, J., Fau-Larson, G., Larson, G., 1999. Codeine concentration in hair after oral administration is dependent on melanin content. Clin. Chem. 45 1485-1494

Kučera, J., Bencko, V., Sabbioni, E., Van der Venne, M.T., 1995. Review of trace elements in blood, serum and urine for the Czech and Slovak populations and critical evaluation of their possible use as reference values. Sci. Total Environ. $166,211-234$.

Larsson, B.S., 1993. Interaction between chemicals and melanin. Pigment Cell Res 6, 127-133.

Li, Y., Yang, L., Wang, W., Li, H., Lv, J., Zou, X., 2011. Trace element concentrations in hair of healthy Chinese centenarians. Sci. Total Environ. 409, 1385-1390.

Llobet, J.M., Granero, S., Schuhmacher, M., Corbella, J., Domingo, J.L., 1998. Biologica monitoring of environmental pollution and human exposure to metals in Tarragona, Spain. IV. Estimation of the dietary intake. Trace Elem. Electrolyte 15 $136-141$.

Luo, R., Zhuo, X., Ma, D., 2014. Determination of 33 elements in scalp hair samples from inhabitants of a mountain village of Tonglu city, China. Ecotoxicol. Environ. Saf. 104, 215-219.

Mandal, B.K., Suzuki, K.T., 2002. Arsenic round the world: a review. Talanta 58 , 201-235.

McLean, C.M., Koller, C.E., Rodger, J.C., MacFarlane, G.R., 2009. Mammalian hair as an accumulative bioindicator of metal bioavailability in Australian terrestrial environments. Sci. Total Environ. 407, 3588-3596.

Monna, F., Galop, D., Carozza, L., Tual, M., Beyrie, A., Marembert, F., Chateau, C., Dominik, J., Grousset, F.E., 2004. Environmental impact of early Basque mining and smelting recorded in a high ash minerogenic peat deposit. Sci. Total Environ. $327,197-214$.

Moreda-Pineiro, J., Alonso-Rodriguez, E., Fau-Lopez-Mahia, P., Lopez-Mahia, P., Fau-Muniategui-Lorenzo, S., Muniategui-Lorenzo, S., Fau-Prada-Rodriguez, D. Prada-Rodriguez, D., Fau-Moreda-Pineiro, A., Moreda-Pineiro, A., Fau-BermejoBarrera, P., Bermejo-Barrera, P., 2007. Determination of major and trace elements in human scalp hair by pressurized-liquid extraction with acetic acid and inductively coupled plasma-optical-emission spectrometry. Anal. Bioanal. Chem. 388, 441-449. 
Nowak, B., Chmielnicka, J., 2000. Relationship of lead and cadmium to essential elements in hair, teeth, and nails of environmentally exposed people. Ecotoxicol. Environ. Saf. 46, 265-274.

Özden, T.A., Gökçay, G., Ertem, H.V., Süoğlu, Ö.D., Kılıç, A., Sökücü, S., Saner, G., 2007. Elevated hair levels of cadmium and lead in school children exposed to smoking and in highways near schools. Clin. Biochem. 40, 52-56.

Peña-Fernández, A., González-Muñoz, M.J., Lobo-Bedmar, M.C., 2014. “Reference values" of trace elements in the hair of a sample group of Spanish children (aged 6-9 years) - are urban topsoils a source of contamination? Environ. Toxicol. Pharmacol. 38, 141-152.

Pereira, R., Ribeiro, R., Fau-Goncalves, F., Goncalves, F., 2004. Scalp hair analysis as a tool in assessing human exposure to heavy metals (S. Domingos mine, Portugal). Sci. Total Environ. 327, 81-92.

Robert, F.G., 1975. In: Gould Robert, F. (Ed.), Arsenical Pesticides, Copyright, ACS Symposium Series FOREWORD. American Chemical Society, pp. i-iv.

Sahoo, S.K., Mishra, S., Žunić, Z.S., Arae, H., Gjergj, F., Stegnar, P., Benedik, L., Repinc, U., Kritsananuwat, R., 2014. Distribution of uranium and selected trace metals in Balkan human scalp hair using inductively coupled plasma mass spectrometry. Int. J. Mass Spectrom. 373, 15-21.

Shalat, S.L., Donnelly, K.C., Freeman, N.C.G., Calvin, J.A., Ramesh, S., Jimenez, M., Black, K., Coutinho, C., Needham, L.L., Barr, D.B., Ramirez, J., 2003. Nondietary ingestion of pesticides by children in an agricultural community on the US/Mexico border: preliminary results. J. Expo. Anal. Environ. Epidemiol. 13, 42-50.

Smith, M.P., Henderson, P., Peishan, Z., 1999. Reaction relationships in the Bayan Obo Fe-REE-Nb deposit Inner Mongolia, China: implications for the relative stability of rare-earth element phosphates and fluorocarbonates. Contrib. Mineral. Petrol. 134, 294-310.
Soldin, O.P., Mattison, D.R., 2009. Sex differences in pharmacokinetics and pharmacodynamics. Clin. Pharmacokinet. 48, 143-157.

Sukumar, A., 2002. Factors influencing levels of trace elements in human hair. Rev. Environ. Contam. Toxicol. 175, 47-78.

Ullrich, S.M., Ramsey, M.H., Helios-Rybicka, E., 1999. Total and exchangeable concentrations of heavy metals in soils near Bytom, an area of $\mathrm{Pb} / \mathrm{Zn}$ mining and smelting in Upper Silesia, Poland. Appl. Geochem. 14, 187-196.

Vahter, M., Åkesson, A., Lidén, C., Ceccatelli, S., Berglund, M., 2007. Gender differences in the disposition and toxicity of metals. Environ. Res. 104, 85-95.

Varrica, D., Tamburo, E., Dongarrà, G., Sposito, F., 2014a. Trace elements in scalp hair of children chronically exposed to volcanic activity (Mt. Etna, Italy). Sci. Total Environ. 470-471, 117-126.

Varrica, D., Tamburo, E., Milia, N., Vallascas, E., Cortimiglia, V., De Giudici, G., Dongarra, G., Sanna, E., Monna, F., Losno, R., 2014b. Metals and metalloids in hair samples of children living near the abandoned mine sites of Sulcis-Inglesiente (Sardinia, Italy). Environ. Res. 134C, 366-374.

Wang, L., Liang, T., 2014. Accumulation and fractionation of rare earth elements in atmospheric particulates around a mine tailing in Baotou, China. Atmos. Environ. $88,23-29$.

Wang, L., Liang, T., Zhang, Q., Li, K., 2014. Rare earth element components in atmospheric particulates in the Bayan Obo mine region. Environ. Res. 131, 64-70.

Wang, T., Fu, J., Wang, Y., Liao, C., Tao, Y., Jiang, G., 2009. Use of scalp hair as indicator of human exposure to heavy metals in an electronic waste recycling area. Environ. Pollut. 157, 2445-2451. 